\title{
The notion of Charter Schools and Its Feasibility in Turkey
}

\author{
Ekrem Solak* \\ Faculty of Education, Amasya University, Amasya, Turkey
}

\begin{tabular}{|c|c|}
\hline \multicolumn{2}{|c|}{$\begin{array}{c}\text { Ayşegül Özaşk1n } \\
\text { Faculty of Education, Amasya University, Amasya, Turkey }\end{array}$} \\
\hline Article history & The purpose of this study was to investigate the feasibility of \\
\hline $\begin{array}{l}\text { Received: } \\
27.02 .2014\end{array}$ & $\begin{array}{l}\text { Charter School system in Turkey, which was opened firstly in State } \\
\text { of Minnesota of United States and was expanded to approximately }\end{array}$ \\
\hline $\begin{array}{l}\text { Received in revised form: } \\
28.03 .2014\end{array}$ & $\begin{array}{l}40 \text { states in America today and also, in practice in some countries } \\
\text { such as Canada, New Zealand, United Kingdom, Sweden and }\end{array}$ \\
\hline $\begin{array}{l}\text { Accepted: } \\
31.03 .2014\end{array}$ & $\begin{array}{l}\text { Norway. Charter Schools are educational institutes that can be } \\
\text { opened by signing a contract between a country's institution }\end{array}$ \\
\hline Key words: & $\begin{array}{l}\text { responsible for education and a person or a group who wants to be } \\
\text { resnonsible for the manaement of this school This system wa }\end{array}$ \\
\hline $\begin{array}{l}\text { Charter Schools, public } \\
\text { schools, private schools }\end{array}$ & $\begin{array}{l}\text { based on performance and accountability and pursued more } \\
\text { competitive and innovative goals. Moreover, Charter Schools put } \\
\text { emphasis on democracy and equality in education by being free, } \\
\text { addressing to all students living in the region where school was } \\
\text { located and considering individual differences and diversity on } \\
\text { behalf of students. Eight volunteering faculty members were } \\
\text { chosen by criterion sampling who were working in the field of } \\
\text { Educational Sciences of universities in Turkey. Interviews were } \\
\text { conducted with participants who were informed about the structure } \\
\text { and operation of this system in advance. The results of the study } \\
\text { suggested that Charter Schools were advantageous in terms of } \\
\text { individualism, diversity and flexible curriculum though flexible } \\
\text { curriculum, monitoring and audition process could lead to some } \\
\text { problems when it was practiced in Turkey. }\end{array}$ \\
\hline
\end{tabular}

\section{Introduction}

The notion of Charter Schools was firstly brought to agenda in United States of America with the "Education by Charter" article which was published in 1974 for the first time. Budde (1988) derived from the topics on the agenda of National Education Commission reports and forums about education and economics which was held in 1980s. Those reports and forums revealed that United States fell behind in comparison to its opponents in the areas of trade, industry and technological innovation and it was emphasized that learning was an indispensable investment in the new information age. American kids were unaware of their

\footnotetext{
*Correspondency: ekremsolak@gmail.com
} 
past and unprepared to future and this ended up with not only dropping out but also abstraction from being a member of a productive society; better schools meant better jobs and unless finding an answer to these problematic issues, Americans could no more maintain their high living standards. Based on these results, Budde called for an educational reform and brought out the notion of Charter schools for the purpose of reorganization of schools. Because United States could not get up to date with new informatics age where knowledge and power are reproduced, this problem created a need about the reconstruction of educational institutes. Besides, as Bowles (2014) stated that, there were political and cultural conflicts in 1960 s, economic inequality as a major problem was perpetually brought forward by minorities, women, students and labors, and laws and governance were held account. In order to appease that social breakdown and to create a social harmony, grant holders intended to amend the existing programs, so the concept of free enterprise was emerged especially for spheres of education and vocational training. For the purpose of listening to demands of disadvantaged groups and sharing in production-oriented new world order, a social reform was focused and reorganization of public schools in compliance with the liberal system and competitive environment was seen as a cornerstone. All in all, "With education, it is aimed on one hand to raise a manpower what economy requires, on the other hand to gain consumer and producer behaviors as required by economic system" (Üstün, 2002).

There are many different ethnic backgrounds in United States and their quest for democracy, liberal economic order, and desire to adapt to the competitive world were all reflected on the education system. Charter school system was a result in the context of reform seeking. Albert Shanker was the second prominent name after Budde about this issue. According to the information given by UFT (United Federation of Teachers), Shanker presided at the American Federation of Teachers that had nine hundred seven members between the years of 19641986. He was at the fore in notable areas such as increasing the budget allocated for education, reducing classroom sizes and preparing more effective curriculum. In 1988, he brought up an alternative school idea which is autonomous, publicly funded and similar to private school system (Kahlenberg, 2008).

After Budde and Shanker, Citizens League Study Committee evolved the Charter School idea and published the proposal in 1988. Minnesota was the first state that imposed this reform in 1991 and deemed worthy of innovation award in 2000. Many states was legislated the regulation in 1990s and now a total of 40 states opened Charter Schools in United States (Kolderie, 2008).

The first Charter School was opened in Minnesota in 1991 and emerged as a result of reforms desired to be made in education. As first Charter School, it has been a pioneer to all country for the preparation to this system (Minnesota Session Law; 1991). By means of "No Children Left Behind (NCLB; 2002)" movement in 2001, Charter School system started to gain momentum. According to the Merriam-Webster dictionary, charter means "a document issued by a government that gives rights to a person or group". Recreating and dynamizing public schools were aimed. Modernization of education, keeping up with competition in all over the world, renewing itself continuously, increasing both quality and diversity and creating a system based on full performance were intended.

Opening a Charter School process starts when a group of teachers or educators comes together and applies to the local board of education. This authorized institution and applicants sign a contract with a logic of renting. According to most of states' Charter School laws and regulations, educational skills that students must gain in a determined time are specified in 
initial contract and this contract renewed considering if contract articles are fulfilled when duration is finished (Minnesota Legislative Reference Library, 2014). There is a correspondence between Charter Schools and both public and private schools in terms of structure and management. Reasons, in parallel to private schools, are uncrowded classes, innovation goal, flexible curriculum, considering desires of trainees and performance-based system. The similarity between Charter and public schools is that they are both publicly funded. All people must have access to publicly funded schools and all applicants should have equal opportunity (Lubienski\&Gulosino\&Weitzel, 2009). Charter Schools are open to all segments of society regardless of race, gender, ethnicity, economic status and etc. In case of more applications than the capacity of these schools, a candidate pool is formed and random selection method is applied. One of the significant goals of Charter School reform is innovative curriculum and it is indented to actualize by performance-based accountability (Miron \& Nelson, 2002). The purpose of a performance-based system is paving the way of innovations in education and setting higher goals by creating a competitive environment. But Gawlik (2012) put forward with his research that a system based on performance and accountability may have some disadvantages. Participants in Gawlik's research were teachers of Charter Schools. Those teachers stated that they put so much effort into implementing numerous educational strategies and creating project-based learning environments, detailed investigation on teacher and student performance created a pressure and this pressure affected their professionalism.

Charter Schools can vary because each state has different charter laws and each school has specific tasks and targets. Authorized entities in that school district monitor Charter Schools in terms of contract articles and contract is renewed after three to five years according to related state's charter laws and regulations (Chen, 2014). Charter Schools' structure is composed of attempting innovative methods that are undertaken in contract, less classroom sizes compared to public schools; focusing on different disciplines and having flexibility in trying new curriculums. In reference to Kamienski's (2011) research done in Chicago, students in public schools (adhere strictly to legal curriculum and obliged to comply with all regulations in state) and students in Charter schools (have flexibility in curriculum and performance-based system) were compared in terms of their SAT (Scholastic Aptitude Test) scores. It was seen that students in Charter Schools had higher SAT scores. Even though students in Charter schools are more successful in academic context because of innovation, having performance based system and accountability features, some variables are not considered such as motivation, support, economic resources, family processes and school employees and their possible contributions to success.

American education system is managed by U.S. Department of Education. According to U.S. Department of Education, the federal role in education is limited and educational policies are decided in local or state basis mostly. The reason for each Charter school gives emphasis on different areas and shows diversity in terms of organizational structures and management types. As Lee (2014) stated, how competitive market structure imposes an obligation to organizations about servicing better to customers and considering their demands, such an educational concept based on accountability and performance can be considered as a system that prioritize desires and needs of students and their families. Charter Schools are accountable for authorized government agencies, teachers, families and benefactors (Hill \& Lake, 2004, s.3). The aforementioned government agencies are School Boards and School District where all educational institutes are registered to. These commissions deal with financial and managerial processes of all educational activities. 
In Turkey, the responsible agency for education and training is Ministry of National Education. The national education system is organized by taking "the Constitution of the Republic of Turkey, education related laws, development plans, national education councils and national programs as basis" (Konan, 2002). The overall structure of educational system in our country is divided into two types as formal and non-formal education. Formal education comprises of preschool education, primary education, secondary education and higher education. Educational institutes expressed with public and private school terms are involved in National Education system, are structured by related ministry and included in formal education system. Educational environments and experiences in all schools are regulated according to criteria set by National Education Ministry. The current Private Education Institutes law was enacted on 08.02.2007 with the law number 5580. In common with public schools, curriculum and educational activities are tempered to principles of related ministry. "The main framework of educational programs is determined by Ministry of National Education, in other words by an administrative centre. Each activity in schools should be involved in these educational programs. These activities comprise planning and programming of lesson plans, group meetings, and pedagogical activities, celebration of special days, excursion and observation activities, in service training activities, guidance services, leisure time activities, relations between school and environment" (Nural, 2002). This monopolist attitude about educational programs has a negative effect on bringing light to different fields and development of individuals with different interests.

It is impossible to discriminate an educational system from other systems in a country. Educational system creates an inseparable whole with economic, political and social systems. In recent years, revisions have been made very often in Turkish education system. Having changes in many areas such as curriculum, names of courses, testing systems, school types, duration of compulsory education, schooling age etc. show that Turkish education system needs revisions in parallel to the improvements in other fields. The centralized structure of educational system in Turkey established an authority in many areas such as content of the curriculum, selection of course books, in-class activities, teaching methods and techniques, organization of classrooms, physical conditions of schools, uniform clothing in schools. "The role of other institutions, local authorities, families and civil initiatives in education system are negligible" (A1, 2013). In such a string of education system, individual features of students and requests of families can be ignored. Creating information society has become an indispensable goal of education in an age where globalization and technology culture diffuses everywhere. However, we are facing a problem whether or not education in Turkey is able to meet the essential qualities that each information literate individual must possess in an information society (Akyüz, 2013).

The purpose of this study is to ask opinions of faculty members in Educational Sciences department about the feasibility of Charter schools in Turkey. It was aimed to examine what kind of a position this innovative system might have in Turkish education system and what kind of results might be obtained from the charter model in current situation.

\section{Method}

Qualitative research design was used in this paper. According to Patton (1995), "Qualitative research is an effort to understand situations in their uniqueness as part of a particular context and the interactions there. This understanding is an end in itself, so that it is not attempting to predict what may happen in the future necessarily, but to understand the nature of that setting-what it means for participants to be in that setting, what their lives are 
like, what's going on for them, what their meanings are, what the world looks like in that particular setting-and in the analysis to be able to communicate that faithfully to others who are interested in that setting. The analysis strives for depth of understanding" (cited by Meriam, 2013, p. 14). It was aimed to reveal opinions of participants about the overall structure of Charter Schools and possible effects in case this system is applied. Also, in accordance with the nature of qualitative research, purposeful sampling and criterion sampling techniques are used. The inspected sample must be a rich seam of information, this lies at the core of the criterion sampling. Thus, main deficiencies of the system can be revealed and it gives opportunities in order to develop the system or program (Patton, 2002). Faculty members of Educational Sciences departments were considered as a rich seam of information and their opinions were asked on a voluntary basis.

Semi-structured interview form was used as a tool for data collection in this research. Questions in the interview form were prepared by considering the related literature and Turkish education system, and views of experts put the last touches on the interview form. Information about organization and general structure of Charter schools were given to participants and they were asked to answer two questions. The first question was about the advantages and disadvantages of Charter schools compared to public and private schools when Turkish education system was considered as a reference. The second question was related to positive and negative sides of Charter School reform in case it was applied in Turkey.

Descriptive analysis, as one of the qualitative data analysis method was used in the analysis of the data obtained from semi-structured interview form. According to Yildırım and Şimşek (2011), "the aim in descriptive analysis is to submit the obtained data to readers in an organized and interpreted form. In descriptive analysis, direct quotations are allowed so often in order to reflect opinions of interviewed or observed individuals conspicuously" ( $\mathrm{p}$. 224). The names of the 8 participants were not given and instead of this, figures like P1, P2, P3,... were assigned to them. NVivo 9 program was used in the arrangement and interpretation of the data.

\section{Findings and Results}

In this section, findings obtained from interview questions are presented.

The first question within the scope of this research was towards the advantages and disadvantages of Charter Schools compared to public and private schools according to the information given in interview form. The second question was addressing the participants' opinions about the feasibility of Charter schools in Turkey. Three themes were identified on the basis of questions on interview form and answers of participants. The first theme is advantages, second theme is disadvantages, third and the last theme is the feasibility of Charter Schools in Turkey.

\section{Theme: The Advantages of Charter Schools}

Participants declared that Charter school system is more advantageous compared to public and private schools. The emergent codes related to advantage theme are as follows: 


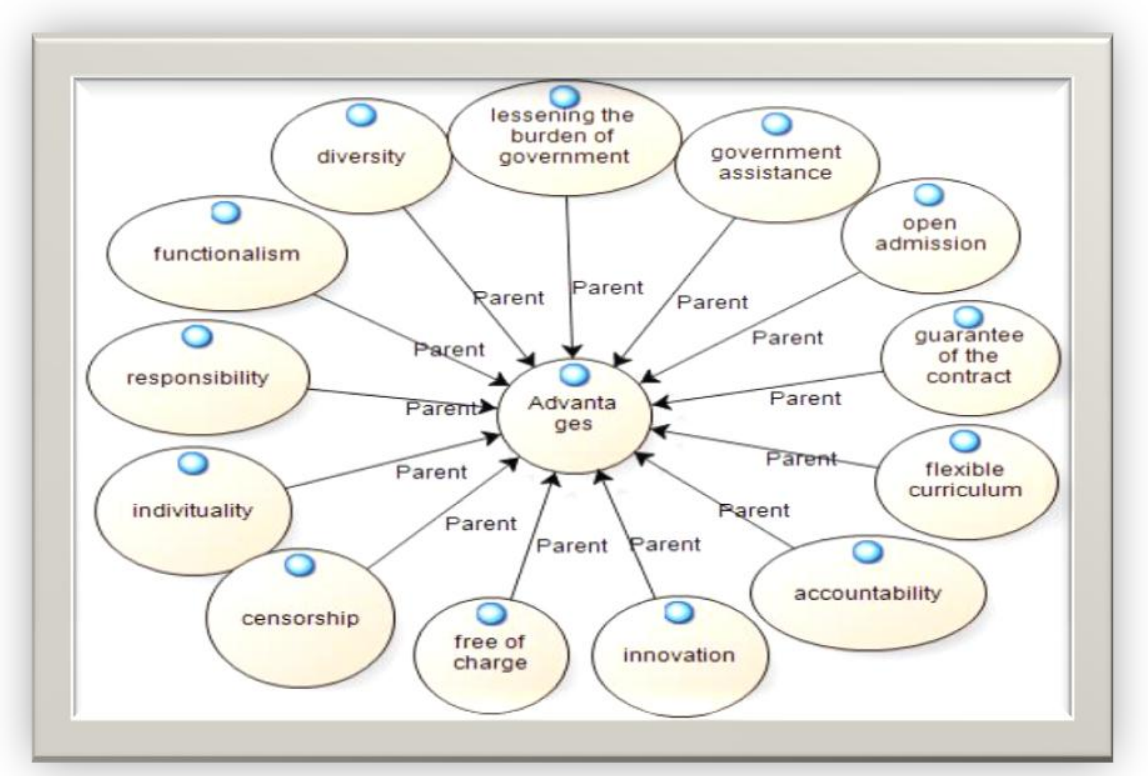

Figure 1: Advantages of Charter Schools compared to Public and Private Schools

Individuality, innovation, flexible curriculum, censorship, diversity, free of charge, accountability, responsibility, functionalism, open admission, government assistance, lessening the burden of government and guarantee of the contract are the advantages of Charter schools specified by participants. The following figure shows which items are used more often:

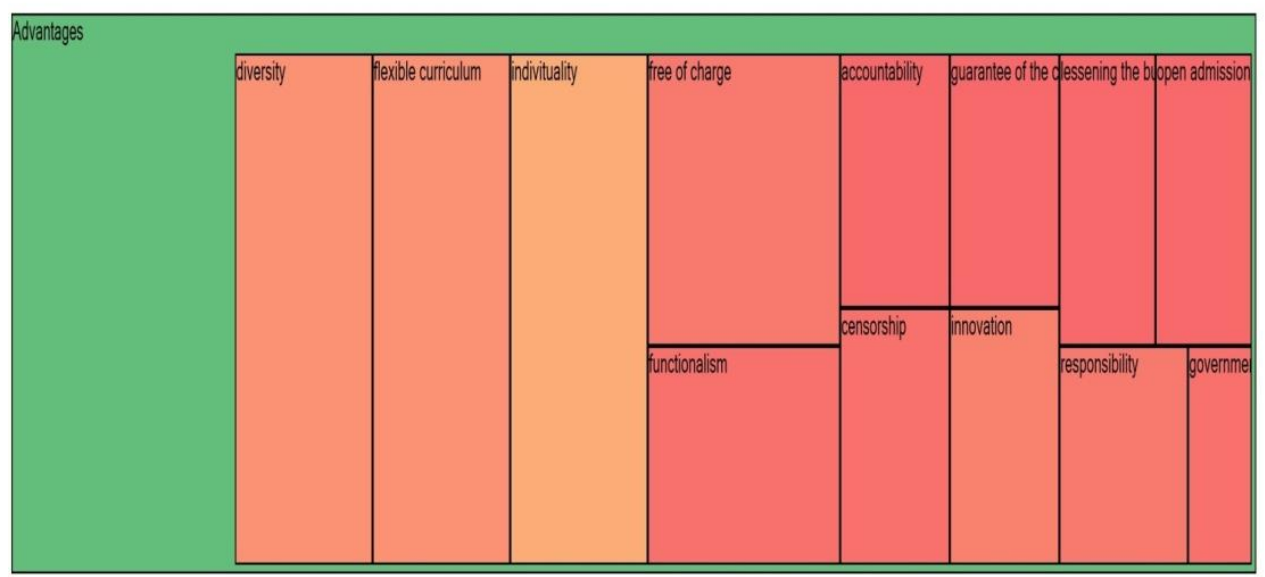

Figure 2: The Prominent items about the advantages of Charter Schools

In Turkey, private schools have a chance to diversify the curriculum and so they can give weight to ignored areas. Also, class sizes are lower compared to public schools and social services they serve are more extensive and varied. Charter schools are publicly funded and open to audition; from this aspect these schools are similar to public schools. In addition, Charter schools are similar to private schools in terms of its structure and management. Moreover, these schools are more flexible about curriculum and teaching methods and techniques compared to private schools in Turkey. All of these features are seen as advantages which make Charter schools different from public and private schools.

P2 stated the following with regard to advantages theme of Charter schools: 
"While the curriculum of public schools is being updated once in five-ten years, Charter schools can update their curriculum annually. Flexible curriculum provides opportunity to select courses according to interests improve oneself in different areas. Features such as being open admission and free of charge increase the interest to these schools. Maybe, this is the most significant concept which makes these schools different from 'private school' statue. By abolishing the 'private-public' discrimination, education is perceived more positive in common. Moreover, it is important to lessen the burden of government. The fact that it is publicly funded and controlled by government gives the impression that the education is being guaranteed by the government. Signing a contract and controlling the obligations prevent the arbitrariness, so it allows perceiving the whole system as an 'open system'. Thus, the relationship between school and environment strengthens. Each individual has a chance to apply to open these schools. Thereby, helping qualified people to join society and paving the way for social development are provided. Being secular, in other words being independent from religions is so important in education. It is a very important development in our day due to prevent the influence of religious and dogmatic effects on the education. Through holding responsible students from their own success, the concept of 'individual education' comes into prominence instead of 'mass education'. The accountability of schools is expressed as 'governance'; this feature enables schools to be perceived more favorable and responsible by society".

Opinions of P3 about the advantages of Charter schools are as follows:

"Costs in private schools belong to the parents. The most outstanding advantage of Charter schools is they do not burden any costs to parents. Parents also have a chance to come together and apply to open such a school. This is very important in terms of accessing to education. Accountability is a positive thing from the standpoint of attaining the objectives of education. Also, contracting for a length of time is important in terms of sustainability of educational objectives".

The following are the opinions of P4 about the advantages of Charter schools:

"In terms of its purpose and functioning, Charter School is an alternative implementation which gives support to education. Controlling by government, being free of charge and being open to everyone even disadvantaged and different people, being free in customizing the education system are big advantages. Considering secularism in such environments prevents education to deviate from its purposes".

The following opinions belong to P6:

"Being a part of an education system which is designed according to the interests of students is so beneficial for both academic achievement and motivation. The present system does not address the student interests, so this problem causes students to concern just only for the grades, not for the content. This also causes to be insensible to school and education. In addition to this, because of economical and environmental conditions, many students do not have chance to go private schools. Some of these students feel themselves insufficient compared to ones who are in private schools. Charter school system is a big advantage for such students. A system can be created in which anyone makes class discrimination by this means".

Opinions of P7 about the advantages of Charter schools are as follows: 
"A flexible curriculum yields to highlight individual differences and it becomes beneficial for individuals to develop themselves".

Based on the examples given above, it can be seen that participants agree on the subject of advantages of Charter schools. Some features as being free of charge, resembling to private schools in terms of structure but being publicly funded as public schools, being accountable and performance-based are seen as advantages of these schools and all these reveal the perception of competitiveness in education. Opinions of P1 about the advantages of Charter schools differ from other participants. P1 stated that:

"I lean towards every practice which lessons the burden of National Education system. Besides, such a reform does not have to be better or more advantageous in proportion to public schools. We should take a look at the functionality of this system. Even, we do not need to charge a mission about being secular on these schools. If we look at the examples in America, we can see that there are many successful schools which belong to religious congregations".

What makes P1 different from other participants is discussing charter system as an alternative novelty which lessens the burden of public schools. This participant approaches to charter system within the framework of accumulation of problems in education system and difficulties in management of it. So, P1 leans toward such a system which has an ability to remove this increasing load day by day. In this context, it does not matter whether or not a secular stance these schools hold. P1 considered that a variety of religious congregations can open Charter schools as long as they lessen the burden of National Education and increase the success.

\section{Theme: Disadvantages of Charter Schools}

Findings related to disadvantages of Charter schools are as follows:

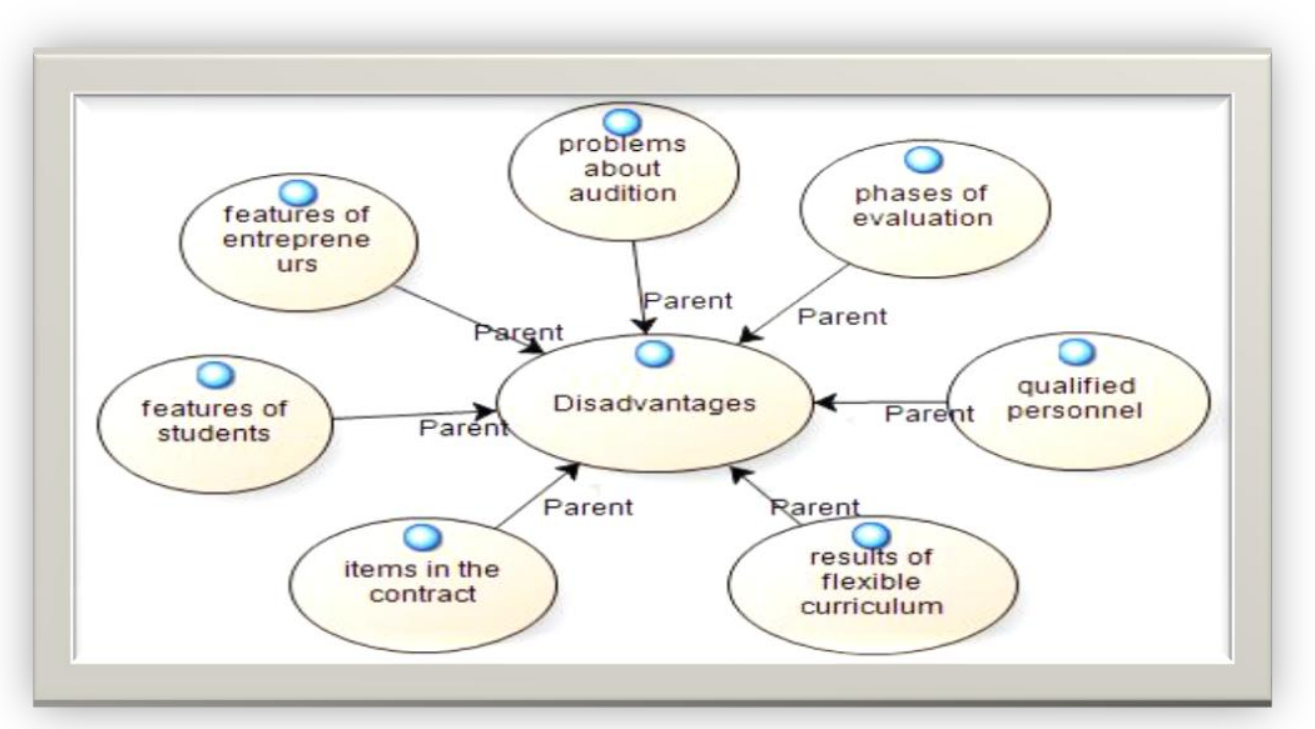

Figure 3: Disadvantages of Charter Schools compared to public and private schools

Problems are led by flexible curriculum, gathering students with different characteristic because of open admission, unable to set criteria and process about evaluation, unable to know the characteristics of entrepreneurs, inexplicit items in contract, lack of confidence about audition process, lack of qualified personnel are the emerging findings in the matter of 
disadvantages of Charter schools. The following figure shows which items are used more often:

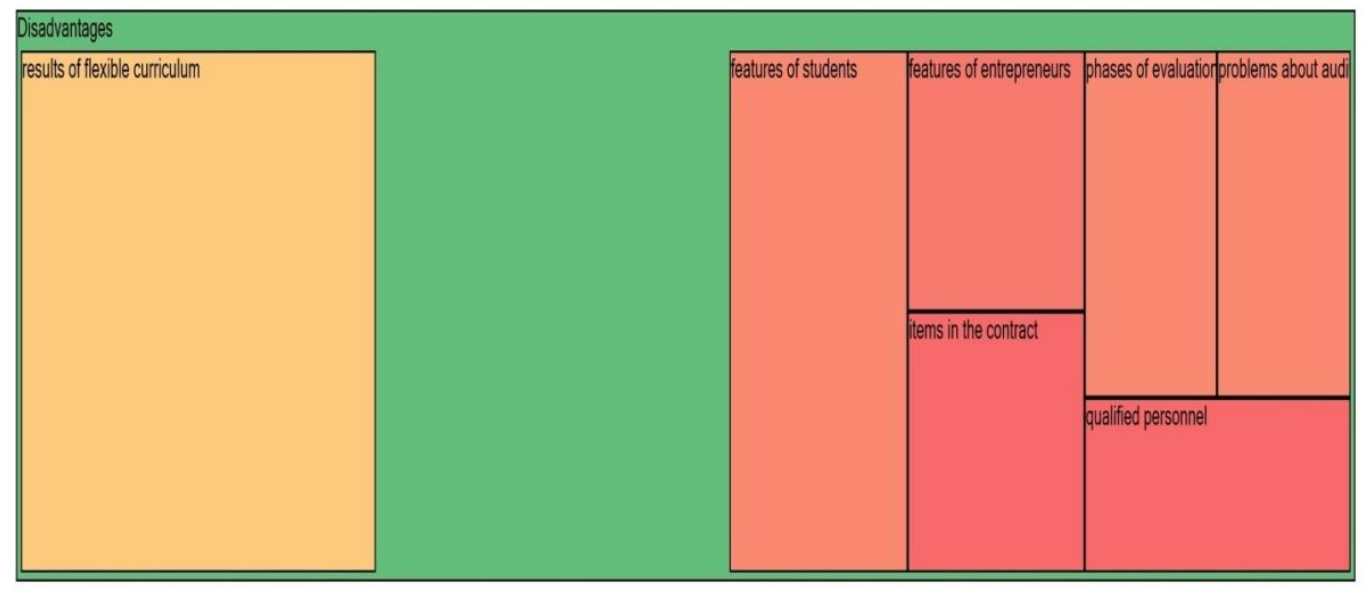

Figure 4: The Prominent items about the disadvantages of Charter Schools

What P4 said about the disadvantages are as follows:

"The flexibility in designing curriculum raises the issue of violation the principle of equal opportunity in those schools".

Opinions of P6 about the disadvantages of Charter schools are as follows:

"If there weren't enough Charter schools and even so excess demand, in other words if supply and demand equilibrium were not provided, only draught students would be able to benefit from this service. This will cause class discrimination and damage the principle of equity in education".

P7 expressed the followings about the disadvantages:

"That kind of education system may cause to meet some problems about not possessing main features that the job market requires in employment".

Ideas of P3 are as follows:

"Opening and managing a school requires particular knowledge and skills. If non-educators are allowed to open schools, this may lead to encounter major problems".

What P8 said about the disadvantages of Charter schools compared to public and private schools are as follows:

"These practices do not seem useful in order to create professionalism, happier and more productive individuals. Charter school system seems as a product of global market oriented scenario. Actually, this system ignores personal growth and personal qualities; it only aims to train appropriate personnel for business world".

P2 said that:

"Audition is the most important part of this process. In the absence of a sufficient control mechanism, these schools become invalid. What kind of sanction will be exposed to ones who 
disregard the contract items is unclear, entrepreneurs will be affected negatively. Finding qualified personnel is difficult, a mismatch between objectives and results can occur. Unless school entrance exams are not made, students may choose schools which are not suitable for them. This makes things difficult for both students and teachers. Drawing system may be objected and prioritizing student capabilities or using different criteria can be requested. Debates about whether or not students in those schools are committed to national values and state may appear. In case of disagreement between stakeholders, the school is adversely affected as a whole. Also, flexible curriculum requires flexible implications. Being open to performance and different methods increases the cost. This may damage the economy system of the state or the donator matter may lead to deform the charter system".

\section{Theme: The Feasibility of Charter Schools in Turkey}

Participants are asked about the feasibility of Charter schools in Turkey. In general, they emphasized the following topics: Turkish education system is not ready for such a reform, problems in education system cannot be solved by this way, there are strong opponents who will not accept such a reform, there may be some opportunist who will try to use this system to obtain commercial profit and there may be some troubles because of the problems in controlling mechanism in Turkey.

Thoughts of P1 about this question are as follows:

"In Turkey, some people are always opponent to any change in education system. They will oppose to this issue as well. They will think such a reform is a privatization and also say benefits of education are made available to someone who supports the government. They will reflect this reform as a regime crisis. Some will find this system contrary to the Law on Unification of Education. Apart from these, there will be people who will adopt this system. But many of them will seek ways how to benefit from charter system, how to open a space for themselves, how to convert this reform to money".

The following are the opinions of P4 about the feasibility of Charter schools in Turkey:

"If we consider the implications about education in Turkey, we can see that Charter school system could not be able to meet the standards as it did in other countries. It can be seen that control mechanism plays a functional role in the establishment and survivability of these schools. Whereas many researches verified that control system in Turkey has many problems. Combination of deficiencies in curriculum and weak control system may lead to encounter some major problems. Also, entrepreneurs may consider this situation as a commercial gain".

The opinions of P3 are as follows:

"Opening and managing a school and maintain educational activities require particular knowledge and skills. If such entrepreneurs attempt to open these schools, of course this system can be applicable in Turkey. But when we regard Turkey and its circumstances, we can easily see that no consensus can be built on certain basic principles and philosophical basis. So, opening these schools can be viewed prejudicially".

Following are the opinions of P2 towards the feasibility of Charter schools in Turkey:

"It is difficult to find donators and entrepreneurs in Turkey. It is possible to see problems 
between stakeholders. Also, I believe that secular education is not possible in Turkey because even people say education is secular; Religious Culture and Moral Knowledge course is still a required course. There may be problems about people who will make the controls about those schools. Education is mostly hold down by public sector, so it is possible that the government may not want to leave this sector to private corporations. Adhering to an agreement is another big problem in our country. Because termination, renewal and sanctions in our laws are not suitable to European standards, we may suffer from some negativity. Also, schools may suffer due to need of domain experts".

Here are the opinions of P8:

"There are problems originating from the existing system without exception of public or private school in Turkey. Such reforms do not solve the problem. Our education system is falling victim to daily superficial politics. Charter system is not applicable because of centralized and authoritarian management of Turkey. However, it may be suitable for preschool education. When we look at the past, Conservatory Secondary Schools got a poor response and they are renamed as Fine Arts High schools. What is more, they can be counted on the fingers of one hand. Also, outnumbering Vocational High Schools are even not functional. As a result, Turkey is not ready yet for more liberal applications".

Majority of the participants expressed that being publicly funded, guarantee of government, flexible curriculum, accountability and responsibility are great advantages of Charter schools. But they said that the system provides benefits in other countries, but this does not mean that it will do the same in Turkey. So all of them foresaw Turkey is not ready yet for such reforms.

\section{Discussion and Suggestions}

This study focused on the notion of Charter Schools and its feasibility in Turkish educational context. According to the views of the participants, there are pros and cons about the application of Charter Schools in Turkey. Al (2004) did a research about charter system and its usability in other areas because charter method in United States took place in educational services as a quest for governance. Although this reform was supported by opposite political poles for a long time, after private sector participated in the management of these schools, adverse opinions were emerged. This reform was made in order to provide equality in education, but the belief that these schools could expand the discrimination increased day by day. Despite these adversities, Al expressed positive opinions about Charter school system in terms of democratization, joining new actors in education, developing and using new methods, leading to change in public schools and eliminating the public schoolprivate school dichotomy.

In another study of $\mathrm{Al}$ (2013), he expressed that doing changes perpetually in Turkey meant that an innovative reform was needed. He mentioned that charter model had some originality, because it gave freedom to students to choose publicly owned schools and its hybrid structure which was constructed by the elimination of public school-private school dichotomy. But in case of using this model in Turkey, he stated that discrimination based on gender, ethnicity, native language and socioeconomic status can be increased further. But he also articulated that all these problems can be overcome and resolved by a detailed and well functioning control mechanism.

Within the scope of participants' answers, Charter schools seem more advantageous compared to public and private schools. Despite the advantages dominated the disadvantages, 
participant do not look positively to the feasibility of Charter school system in Turkey. They argue that the current system prevents such innovations. Even though this model is available in United States and in different countries and brings success, it is necessary to evaluate Turkey in its authentic context that takes shape by its history, unsteady periods, political developments, geopolitical position, economy and social structure. In this context, negative opinions are expressed by far on the issue of feasibility of charter model.

Surely, this model can bring dynamism to education by competition servicing like a private school but being publicly funded. But in a system where control mechanism has problems, alternative and liberal methods like Charter schools can do more harm than good. Sustainable education is precluded because of policies which are altered in each government period. Unstable policies will cause difficulties in terms of implementation, management, controlling and taking sanitary feedback. Whereas employment guarantee for future has not provided yet for any scholars at universities, an initiative which aims to train staff for competitive market according to current conjuncture of the country will cause problems. It is essential to have a detailed, strict and objective control mechanism because of the criticism about privatization of education. All in all, it can stated that Charter school reform can be applicable in Turkey under well functioning control mechanism.

\section{References}

Al, Hamza. (2014). Eğitim Hizmetlerinin Sunumunda Yönetişim Arayışları: Charter Yöntemi. [A search for governance in educational services]. Bilgi Ekonomisi ve Yönetimi Dergisi, 9:1, 127-136.

Al, Hamza. (2013). Eğitim Yönetiminde Charter Modeli ve Türkiye'de Uygulanabilirliği. [ Charter Model In the Management of Education And its Applicability in Turkey]. Sakarya İktisat Dergisi, 4, 23-40.

Akyüz, Y. (2013). Türk Eğitim Tarihi: M.Ö. 1000-M.S.2013 [The History of Turkish Education: B.C.1000-A.D.2013]. Pegem Akademi.

Budde, R. (1988). Education by Charter: Restructuring School Districts. Key to Long-Term Continuing Improvement in American Education. The Regional Laboratory for Educational Improvementof the Northeast \& Islands. Massachusetts:U.S.A

Bowles, S. (2014). Schooling in capitalist America: Educational reform and the contradictions of economic life. Haymarket Books. U.S.A

Chen, G. (2014). What is a Charter School? Retrieved from http://www.publicschoolreview.com/blog/what-is-a-charter-school

Gawlik, M. A. (2012). Moving Beyond the Rhetoric: Charter School Reform and Accountability. The Journal of Educational Research, 105:3, 210-219, DOI: 10.1080/00220671.2011.559492.

Hill, P. T., \& Lake, R. J. (2004). Charter schools and accountability in public education. Brookings Institution Press.

Kahlenberg, R. D. (2008). The Charter School Idea Turns 20: A History of Evolution and Role Reversals. Education Week. Retrieved from http://www.edweek.org/ew/articles/2008/03/26/29kahlenberg_ep.h27.html

Kamienski, A. (2011). Competition: Charter and Public Elementary Schools in Chicago. Journal of School Choice: International Research and Reform, 5:2, 161-181, DOI: 10.1080/15582159.2011.576573.

Kolderie, T. (2008). How the idea of 'chartering' schools came about: What role did the Citizens League play? Minnesota Journal. Retrieved from 
http://www.educationevolving.org/pdf/Origins-of-Chartering-Citizens-LeagueRole.pdf

Konan, N. (2002). Türkiye Eğitim Sisteminin Yaplsı.[The structure of Turkish Education System] Erdal Toprakçı (Ed.), in Eğitim Üzerine (p. 265-290). Ütopya.

Lee, J. (2014). The Mechanism of State Charter School Policy Adoption: The Case of American States. International Journal of Public Administration, 37, 20-34, doi: 10.1080/01900692.2013.809589

Lubienski, C., Gulosino, C., Weitzel, P. (2009). School Choice and Competitive Incentives: Mapping the Distribution of Educational Opportunities across Local Education Markets. American Journal of Education, 115, 601-647.

Merriam, S.B. (2013). Nitel Araştırma: Desen ve Uygulama için bir Rehber [Qualitative Research: A guide for design and implementation]. Ankara: NOBEL.

Minnesota Legislative Reference Library (2014). Resources on Minnesota Issues: Charter Schools.

Retrieved

from http://www.leg.state.mn.us/lrl/issues/issues.aspx?issue=charter

Miron, G., \& Nelson, C. (2002). What's public about charter schools: Lessons learned about choice and accountability. Thousands Oaks, CA: Corwin Press.

No Children Left Behind Act of 2001, Pub. L. No. 107-110, 2204 (2002).

Patton, M.Q. (2002). Qualitative Research \& Evaluation Methods (p. 238). California: SAGE.

The Office of the Revisor of the Statues, 1991 Minnesota Session Laws, Chapter 265-H.F.No. 700. Retrieved from https://www.revisor.mn.gov/laws/?id=265\&year=1991\&type=0

United Federation of Teachers, UFT History, Albert Shanker. Retrieved from http://www.uft.org/who-we-are/history/albert-shanker

U.S. Department of Education. Laws \& Guidance. Retrieved from http://www2.ed.gov/policy/landing.jhtml?src=rt

Üstün, A. (2002). Eğitimin Ekonomik Temelleri. [The economic foundations of education]. Erdal Toprakçı (Ed.),in Ĕgitim Üzerine (p. 241-264). Ütopya.

Yıldırım, A. \& Şimşek. H. (2011). Sosyal Bilimlerde Nitel Araştırma Yöntemleri. [qualitative research techniques in social sciences]. Ankara: Seçkin. 